\title{
New species of Papua New Guinea Staphylinidae (Coleoptera)
}

by

\author{
Horace LAST *
}

With 10 figures

\begin{abstract}
Nine new species of New Guinean Staphylininae are described: Philonthus ullrichi, P. pseudolus, Hesperus obesus, H. rarus, Gabrius fuscus, G. kainpitensis, Neobisnius loebli, Amelinus punctus, and Belonuchus coloratus. The types are deposited in the Geneva Museum of Natural History.
\end{abstract}

The Papuan Staphylininae fauna is rich and includes many species with conspicuous morphological characters or colour patterns. Although I have already examined material from several important collections, numerous new taxa are still to be found. Among staphylinids collected by W.G. Ullrich in Papua New Guinea (Geneva Muséum d'histoire naturelle) were nine new species. Their descriptions are given below.

My thanks are due to I. Löbl, Geneva, for the loan of material, and to my friend $\mathrm{J}$. Cooter for typing and preparing the paper for publication.

\section{1 - Philonthus ullrichi n. sp.}

Holotype o* unique. Kainantu, Onerunka, III.1980.

Length $14 \mathrm{~mm}$.

This species is very similar to Philonthus sharpi Fauv. but differs as follows. It is larger, the head differently shaped, antennae more robust and segments not so slender, puncturation of the abdomen not so dense.

* Woodville, Hillside Walk, Storrington, W. Sussex RH 20 4ED, England. 
Legs and basal segments of the antennae ferrugineus, last segments cream-coloured, elytra dull blue, aedeagus figs 1 and 2 .

Head transverse $(8.5: 6.5)$ rectangular, eyes not very convex, from above a little shorter than the temples where there are a few umbilicate punctures all bearing bristles; with very confused microsculpture.

Pronotum a little broader than long (8: 6.5) anterior corners distinct, posterior corners broadly rounded, with fine alutaceous microsculpture and long bristles especially on anterior corners; two dorsal rows of four punctures.

Elytra as long as broad, moderately densely punctured and with short setae and a few long lateral bristles.

Scutellum large, densely punctured.

Abdomen moderately densely punctured, with long slender bristles.

Legs setose and spinose more so on tibiae.

Named after Dr. W.G. Ullrich, the collector.

\section{2 - Philonthus pseudolus n. sp.}

Holotype ơ Kainantu, X.1979.

Paratypes 14 ơ ơ 11 @ Onerunka, VII.1981; 1 Rintobe, V.1979.

Length 11-13 mm.

This species can be compared with the ubiquitous Philonthus politus (L.). The puncturation of the elytra and the abdomen is not so dense and it does not have the transverse triangularly produced line at the base of the three visible tergites. The head is also different with more distinct posterior corners the aedeagus also exhibits differences. This organ bears some resemblance to that of Quedius curtipennis Bernh. (Figs 3 and 4).

Head transverse $(7: 5.5)$ with fine microsculpture and two large inter-ocular punctures and others on the temples, all umbilicate; eyes not very convex, from above twice the length of the temples; antennae with second and third segments of equal length, four and five quadrate, six to ten transverse, last segment emarginate, all finely setose.

Pronotum slightly transverse $(6.5: 8)$ anterior corners distinct, posterior corners broadly rounded, with alutaceous microsculpture and a few long outstanding bristles.

Elytra quadrate, moderately closely punctured and with short decumbent setae and a few long lateral bristles.

Scutellum large and setose.

Abdomen slightly narrowing to the apex, moderately strongly punctured with longer bristles from the last two sternites. Legs robust, setose and spinose more so on tibiae, male with the anterior tarsi strongly dilated.

\section{3 - Hesperus obesus n. sp.}

Holotype $\odot$ unique, Onerunka, near Kainantu, XII.1980.

Length $17 \mathrm{~mm}$.

This species is similar to Hesperus candidus Last but differs in having all segments of the antennae shorter, eyes not so convex, puncturation of the elytra denser and colour not so brilliant. 

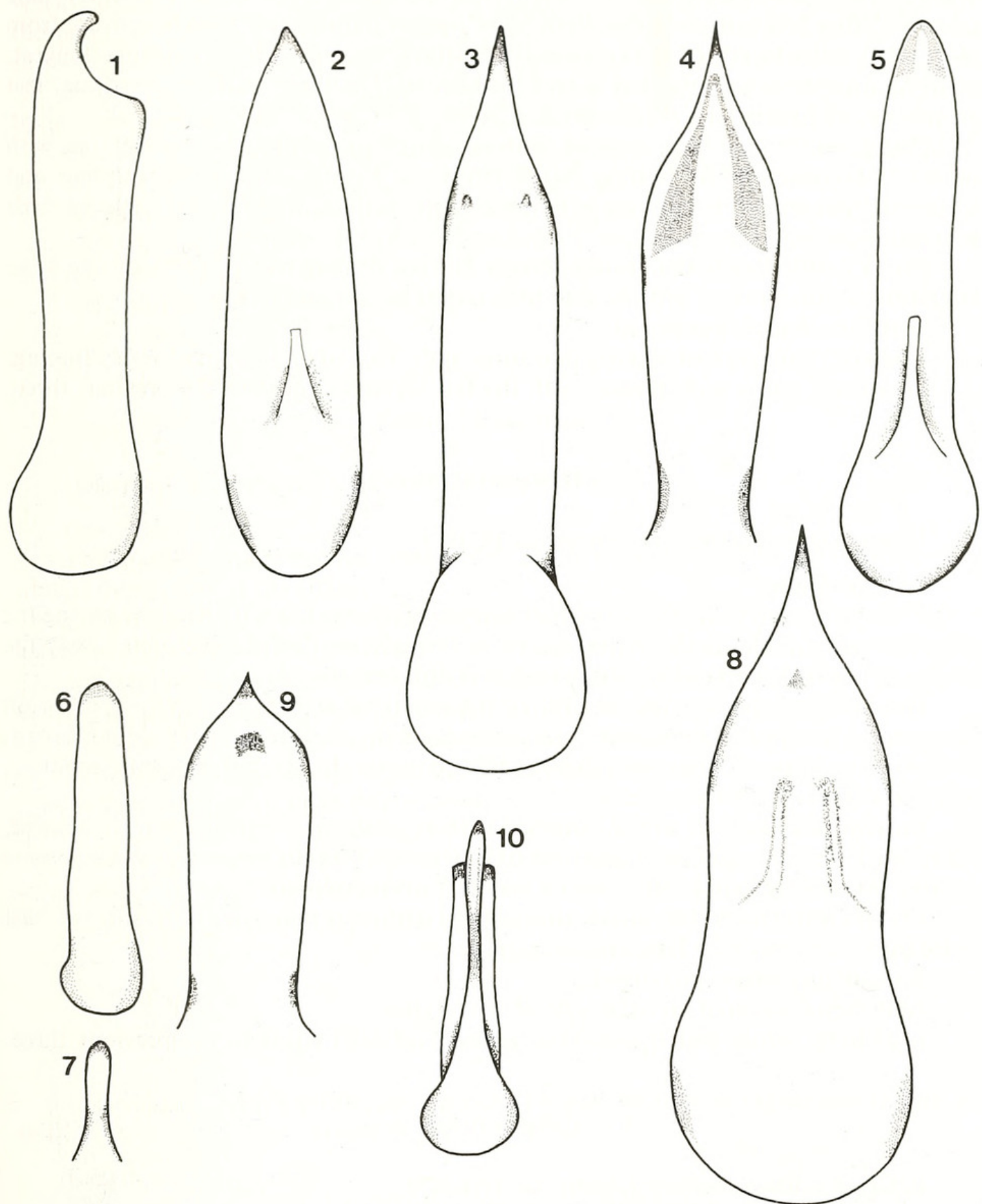

FIGS 1-10.

Figs 1 and 2: aedeagus of Philonthus ullrichi n. sp. (1 lateral view, 2 dorsal view); 3 and 4: aedeagus of Philonthus pseudolus n. sp. (3 median lobe, 4 inner surface of paramere); 5: aedeagus of Hesperus rarus n. sp. 6 and 7: aedeagus of Neobisnius loebli n. sp. (6 median lobe, 7 paramere); 8 and 9: aedeagus of Amelinus punctus $\mathrm{n}$. sp. (8 median lobe, 9 paramere); 10: aedeagus of Belonuchus coloratus $\mathrm{n}$. $\mathrm{sp}$. 
Black, last three segments of the antennae yellowish-white, elytra metallic purple.

Head transverse $(9.5: 7)$ with a few umbilicate punctures on the temples, with very fine microsculpture and extremely fine "pin-point" puncturation, eyes weakly convex, from above, twice the length of the temples. Basal three segments of the antennae longest, segments four to ten shorter but longer than broad, last three segments quadrate, last acuminate, all having long slender bristles.

Pronotum about as long as broad, with two dorsal rows of two large punctures, with others at anterior corners bearing rather long erect bristles, with microsculpture and scattered "pin-point" punctures, anterior corners distinct, narrowing a little towards posterior margin.

Elytra a little longer than broad, evenly but not densely punctured, with fine setae interspersed with stronger bristles, also with lateral bristles, shining.

Scutellum densely punctured.

Abdomen strongly and coarsely punctured at the base of tergites, moderately shining. Legs long, setose and spinose, with the last segments equal to the previous three.

\section{$4-$ Hesperus rarus n. sp.}

Holotype ơ unique, Kainantu, Onerunka, IX.1979.

Length $15 \mathrm{~mm}$.

This species can be compared with Hesperus conciliatus Last. It differs by having the antennae entirely black, the elytra are more strongly but less densely punctured, the abdomen is almost impunctate, the aedeagus is different (Fig. 5).

Head flat, transversely rounded (9:7) with two inner ocular punctures and a few on the temples, a very fine microsculpture. Antennae with all segments longer than broad, basal three very long, four to seven shorter, eight to ten yet shorter, last segment acuminate, all segments with rather long setae.

Pronotum as long as broad, anterior corners distinct, posterior corners rounded, laterally a little converging, with two rows of four punctures with others at anterior corners bearing moderately long bristles; with a very fine microsculpture.

Elytra a little longer than broad, strongly and uniformly punctured, interstices at least twice their diameter; with long bristles, shining.

Scutellum sparingly punctured.

Abdomen punctured on either side of the tergites.

Legs long, setose and spinose, last segment of tarsi equal to the previous three.

\section{5 - Gabrius fuscus n. sp.}

Holotype $\subsetneq$ unique. Kainantu, Onerunka, 1.VI.1979.

Length $10 \mathrm{~mm}$.

This species is similar to the European Gabrius astutus (Er.) and also G. plumosus Last (from Papua New Guinea).

From the former it differs as follows, the antennal segments are more elongate, the head transverse with several strong punctures, pronotum more elongate, puncturation of the elytra is a little finer, legs black. From plumosus, the head is more transverse and more heavily punctured; from both species by its more robust build. 
Head orbicular, a little transverse, with strong puncturation on inner margins of eyes which extends towards the vertex. Eyes not very convex from above equal to the length of the temples. Antennae with all segments longer than broad especially the three basal, segments four to ten shorter, last segment longer than the penultimate and emarginate.

Pronotum a little longer than broad, parallel-sided, with two rows of seven moderately large punctures.

Elytra longer than broad, broader at posterior margins where they are weakly sinuate, very finely and densely punctured.

Scutellum large and finely punctured.

Abdomen with tergites finely and moderately densely punctured and pubescent, shining.

Legs with short spines on tibiae.

\section{6 - Gabrius kainpitensis n. sp.}

Holotype $\subsetneq$ and paratype $\subsetneq$ Morobe, Kainpit, 30.IX.1979.

Length 4.5-5 mm.

This species is quite distinct from others of the genus because of the reddish-yellow which covers most of the elytra.

Black except for the legs, a large area of the elytra, the basal three segments of the antennae and the labial and maxillary palpi which are yellow or reddish-yellow.

Head rounded, eyes not very convex, a little longer than the temples, shining, with two interocular punctures and a few punctures on the inner margins of the eyes.

Pronotum a little longer than broad, with two dorsal rows of five punctures, shining.

Elytra a little longer than broad $(3.25-2.75)$ broader at posterior margins, moderately densely punctured, with short yellow setae.

Scutellum with fine punctures.

Abdomen parallel-sided, tergites moderately densely punctured, with scanty fine yellow setae, shining.

Legs with small spines, especially on tibiae.

\section{7 - Neobisnius loebli n. sp.}

Holotype o Kokina, 1.V.1979; paratypes (2 ex) Morobe VI.1979, also (8 ex) same locality, but 16.IX.1979.

Length 6-7 $\mathrm{mm}$.

This species is smaller than Neobisnius madangensis Last and larger than N. novus Last. The antennal segments are longer than broad as in madangensis, but in novus, with the exception of the basal three they are quadrate to transverse.

Black, except the tibiae and tarsi which are ferrugineus maxillary palpi reddish-yellow, base of antennae obscurely red.

Head orbicular, a little broader than long, with moderately large scattered punctures, eyes not very convex, from above slightly shorter than the temples where there are a few porrect bristles, shining. Antennae with all segments longer than broad, third segment a 
little longer than the second, fourth to the tenth shorter, last segment longer than the penultimate.

Pronotum a little longer than broad, posterior corners more distinct, parallel-sided, with two irregular rows of fairly large punctures, shining, with moderately long setae.

Elytra longer than broad (5.5-4.5) broader at posterior margins, very finely and densely punctured and pubescent.

Scutellum large and finely punctured.

Abdomen with tergites finely punctured, more densely at the base of each.

Legs slender, moderately setose and spinose.

Aedeagus (Figs 6 and 7).

\section{8 - Amelinus punctus n. sp.}

Holotype $\sigma^{*}$, Kainantu, Onerunka, 26.IX.1979. Paratypes $2 \&$ \& same data, $2 థ \uparrow$ same locality but XII.1980; 1 \& Morobe II.1980; 10 Rintobe, 30.I.1979; 1 \& Goroka, 24.VII.1971 (R. Hornabrook).

Length 13-14 mm.

Similar in appearance to Amelinus densipennis Bernh. (from Nigeria) but differs as follows, the antennae are short and black at the base, the penultimate three or four segments including the last are transverse and creamy-white in colour; the humeral corners possess a few silvery setae which are absent in densipennis.

Head almost as broad as long, with moderately large scattered punctures, some umbilicate, those on the temples with porrect bristles, eyes not very convex, from above almost as long as the temples which are straight; very shining. Antennae with second and third segments of equal length, fourth a little longer than broad, fifth and sixth quadrate, seventh to tenth a little transverse, last segment emarginate.

Pronotum almost circular, strongly punctured, leaving a broad elongate impunctate central area, very shining, with a few setae on the anterior corners.

Elytra almost as long as broad, strongly and moderately densely punctured, with decumbent setae, shining.

Scutellum strongly punctured.

Aedeagus (Figs 8 and 9).

Abdomen shining, tergites with elongate punctures.

Legs setose and spinose especially on anterior and intermediate tibiae.

\section{9 - Belonuchus coloratus n. sp.}

Holotype or Onerunka, near Kainantu, X.1973. Paratypes 86 ex. same locality, various dates from IX.1979 to I.1980.

Length $8 \mathrm{~mm}$.

In colouration, this species is similar to Quedius cyaneorufus Fauv., but is quite different in most other respects as well as being generically distinct. It is smaller than Belonuchus bultemensis i.l. and the aedeagus is also different, Fig. 10.

Head, pronotum, legs (excepting the femora and tibiae which are darker) and base of antennae reddish-yellow, elytra purpleblack, abdomen and suture black. 
Head flat, a little broader than long (5:4) rectangular, a little broader than the pronotum, with a large puncture between the centre of the eyes, also one or two at the inner margins, each bearing porrect bristles, moderately shining, without microsculpture. Eyes not very convex, from above shorter than the temples. Antennae with first segment longest, segment three longer than two, four to six a little longer than broad, seven to ten quadrate, last segment longer than the penuitimate, sparingly setose.

Pronotum a little longer than broad, with two rows of three or four punctures, with long porrect bristles laterally; shining.

Elytra as long as broad, moderately strongly and densely punctured, with short black pubescence and lateral bristles.

Scutellum finely and densely punctured.

Abdomen narrowing to the apex, puncturation not dense, moderately fine.

Legs setose. 


\section{$2 \mathrm{BHL}$ Biodiversity Heritage Library}

1989. "New species of Papua New Guinea Staphylinidae (Coleoptera)." Revue suisse de zoologie 96, 877-883. https://doi.org/10.5962/bhl.part.82067.

View This Item Online: https://www.biodiversitylibrary.org/item/128799

DOI: https://doi.org/10.5962/bhl.part.82067

Permalink: https://www.biodiversitylibrary.org/partpdf/82067

\section{Holding Institution}

Smithsonian Libraries

\section{Sponsored by}

Biodiversity Heritage Library

\section{Copyright \& Reuse}

Copyright Status: In Copyright. Digitized with the permission of the rights holder.

Rights Holder: Muséum d'histoire naturelle - Ville de Genève License: http://creativecommons.org/licenses/by-nc-sa/3.0/

Rights: https://www.biodiversitylibrary.org/permissions/

This document was created from content at the Biodiversity Heritage Library, the world's largest open access digital library for biodiversity literature and archives. Visit BHL at https://www.biodiversitylibrary.org. 